\title{
Mystical Kinship of Creation: A Foundation of Eco-spirituality for Interreligious Ecological Movements
}

\author{
Stefanus Christian Haryono \\ Universitas Kristen Duta Wacana, Yogyakarta, Indonesia \\ Email: sch@staff.ukdw.ac.id
}

\begin{abstract}
This study focuses on the intersection between Bhumi Devi in Hindu Mythology and the Canticle of Creation of Saint Francis of Assisi. Both themes, mythology of Bhumi Devi and Canticle of Creation, which are rooted in different traditions, Hinduism and Christianity, enlighten interreligious ecological movements. They propose spiritual foundation as well as concrete actions. This intersection discovers the concept of the mystical kinship of creation as a foundation of eco-spirituality. The author employs an analytical approach to the intersection between Bhumi Devi in Hindu Mythology and the Canticle of Creation of Saint Francis of Assisi. The analysis of two religious traditions entails descriptive discourse of eco-spirituality in the interreligious context. Interdisciplinary research is to find the discourse of eco-spirituality. This approach involves interdisciplinary theories that are interrelated with various scientific concepts. The study found that mystical kinship of creation is deeply rooted in the classical wisdom of creation that can be regarded as the foundation for interreligious ecological movements in the today world. All religions and beliefs have responsibility toward ecological crisis as a global problem. It is not just a responsibility of environmentalism activists, but each one of us has to think globally - act locally-concretly with regard to eco-spirituality. Ecological crisis is an human problem across genders, socioeconomic statuses, ethnicities, religions, and nations.
\end{abstract}

Keywords: Prthivi, mystical kinship, panentheism, eco-spirituality, St. Francis of Assisi

Abstrak: Penelitian ini berfokus pada perjumpaan antara Bhumi Devi dalam Mitologi Hindu dan Canticle of Creation of Saint Francis of Assisi. Kedua tema ini, mitologi Bhumi Devi dan Canticle of Creation yang berakar pada dua tradisi yang berbeda, Hindu dan Kristen, mencerahkan gerakan ekologis antar agama. Tema-tema ini merupakan fundasi spiritual serta mendesakkan tindakan konkret. Perjumpaan ini sampai pada konsep kekerabatan mistis penciptaan sebagai fondasi eko-spiritualitas. Penulis menggunakan pendekatan analitis untuk mengurai perjumpaan antara Bhumi Devi dalam Mitologi Hindu dan Canticle of Creation of Saint Francis of Assisi. Analisis dua tradisi keagamaan memerlukan wacana deskriptif eko-spiritualitas dalam konteks dialog interreligius. Penelitian interdisipliner ini untuk menemukan wacana eko-spiritualitas. Pendekatan ini melibatkan teori interdisipliner yang terkait dengan berbagai konsep ilmiah. Studi ini menemukan bahwa kekerabatan mistik penciptaan sangat berakar pada kebijaksanaan klasik penciptaan yang merupakan fondasi untuk gerakan ekologis antar-agama hari-hari ini. Semua agama dan kepercayaan memiliki tanggung jawab terhadap krisis ekologis sebagai perkara global. Halnya tidak hanya merupakan tanggung jawab aktivis lingkungan, tetapi masing-masing dari kita harus berpikir secara global - bertindak secara lokal dan konkret sehubungan dengan eko-spiritualitas. Krisis ekologis adalah masalah manusia di segala jenis gender, status sosial-ekonomi, etnis, agama, dan bangsa.

Kata kunci: Prthivi, kekerabatan mistik, panenteisme, eko-spiritualitas, St. Fransiskus dari Assisi

\section{Introduction}

Enviromentalism is comparable to a child that only recently learned to walk. Ecospiritualities of different kinds seem to be the invisible backbone of the growth of the child (Jain, 2011, p. 5).

The quotation, which is written by Sigurd Bergmann; emphasizes that a concern for environmental issues through ecological movements in societies are not enough. The movements show the surface layer. What is needed is more fundamental layer; eco-spirituality. In the midst of ecological crises of 
the $21^{\text {st }}$ century, individuals should be aware that ecology is not only about the material world, but also about myth, spirit, and values. Ecology is a life, a habitus. The ecological crises have become a global issue.

In this article, I will explore an eco-spirituality from two perspectives, one from Hindu mythology, specifically the concept of Mother Earth, and the other from St. Francis of Assisi in the Canticle of the Creatures as a representative from Christian theology. The most significant intersection of the two perspectives is the image of creation's kinship. The Prthivi Sukta, Bhumi Devi or Bhu Devi, bearing the image of Mother Earth, and the Canticle telling the image of sibling: brother and sister. Both Hinduism and Christianity have similar myths of creation in their own traditions. On the one hand, anthropomorphism has become the scapegoat of the ecological crises but on the other hand, Hindu mythology and St. Francis of Assisi use personification for creation. Then, what are the intersections between these perspectives that can be built into the foundation of eco-spirituality? How can we build an eco-spirituality from interreligious perspectives?

Based on these questions above, I propose the mystical kinship of creation as a foundation of ecospirituality for interreligious ecological movements. My exploration will focus on three intersections from the Hindu mythology and the Christian theology: the personification, the four basic elements of creation, and the mystical kinship of creation. Then, I propose an eco-spirituality based on the three intersections for interreligious ecological movements.

I want to explain in advance the terminologies that I use. First, the term of Hindu mythology refers to broad narrative traditions of Hinduism across centuries. I will not focus on a particular myth, such as Purānas tradition or Upanisad tradition, and so on. Second, I prefer the term eco-spirituality rather than term eco-spirituality. Term eco-spirituality, has a meaning of 'mixture inherently' from the beginning of the creation process. This is different from eco-spirituality, which means two different aspects: ecology (material) and spiritual (spirit) which refer to some activist, scientist, and religious scholars developing ecology and spirituality, respectively, and the mixing ecology and spirituality together. Ecospirituality needs to come from the creation itself and not be imposed on creation by particular traditions. The topic of this article is of utmost importance and has great value to me as an Indonesian Christian. In fact, Indonesian wisdom has been influenced by Hindu mythology since the $5^{\text {th }}$ century.

\section{Method}

In this article, the author employs an analytical approach to the intersection between Bhumi Devi in Hindu Mythology and the Canticle of Creation of Saint Francis of Assisi. The analysis of two religious traditions entails a descriptive discourse of eco-spirituality (Lincoln, 2000) in the interreligious context. Interdisciplinary research is to find the discourse of eco-spirituality. This research involves interdisciplinary theories that are interrelated with various scientific concepts (Pilario, 2020; Rampisela, 2020; Wilfred, 2020).

\section{The Personification of Creation}

\section{Hindu Mythology}

In Hindu mythology, the earth is "always referred to in the feminine gender" because it is associated with the name of goddesses: "Prthivi and Bhumi, with variations yielding the terms Prthivima and Bhu 
Devi" (Chapple, 2007, pp. 207-208). One classic source from the $5^{\text {th }}$ century BCE is the Prthivi Sukta which described the female image for the earth as a mother:

O Mother Earth!

Instill in me with abundance that fragrance which emanates from you and from your herbs and other vegetation, as well as waters.

This fragrance is sought by all celestial beings.

O Mother Earth!

May that perfume come to us in abundance, the perfume come to us in abundance,

the fragrance worn by gods when the sun marries the dawn.

O Mother Earth!

The fragrance that you have granted to men and women and which is also present in horses, deer, and elephants, shines like the radiance in maidens.

May that radiance come to us.

Bless us with ... fragrance ...

Grant us peace, tranquility,

fragrant air and other worldly riches (Chapple, 2007, p. 206).

Mother is a powerful image of the earth which relates to human existence, for "nothing would exist without her" (Chapple, 2007, p. 218). Perfumes or fragrances remind for humanity of Mother Earth, "from the smell of the earth to the power of human memory" (Chapple, 2007, p. 217). The Mother Earth shows care through the herbs from which "medicines arise from the earth" (Chapple, 2007. p. 206). Moreover, the Mother Earth gives peace for the well-being of other creatures. The shouting, "O Mother Earth!" shows an intimate interpersonal relationship between the earth and humans as a confession that "My mother is this earth, and I am her son," "You are the world for us and we are your children" (Chapple, 2007, p. 206). Christopher Key Chapple in his chapter "The Goddess and Ecological Sensitivity," argues that Prthivi Sukta carries "a clearly anthropocentric message," based on the existence of Mother Earth for human's satisfaction (Chapple, 2007, p. 207).

The interpersonal relationship between mother and child is not always in harmony but also in struggle because the children make pollution. The next stanza shows the pollution to water, and the trouble on the road of the earth:

O Mother Earth!

May our bodies enjoy only the clear water.

May you keep away from us that which is polluted

and may we do only the good deeds.

O Mother Earth!

You have given people many roads

where both the chariots move and bullock-carts with grains ply,

where both the virtuous and wicked people travel.

Protect these networks of transportation from robbers and thugs.

May we be victorious and may we receive

the auspicious and benevolent things in life (Chapple 2007, p. 206). 
The figure of Mother Earth is also known as Bhu Devi or Bhumi Devi. Vijaya Rettakudi Nagarajan affirms "Bhumi Devi is our mother. She is everyone's source of existence. Nothing would exist without her. The entire world depends on her for sustenance and life" (Nagarajan, 1998, p. 273). She is "small, fragile, and feminine" (Nagarajan, 1998, pp. 271-272). The stanza expresses the vulnerability of Mother Earth, she is not a super woman's figure. The vulnerability of Mother Earth shows that a "disastrous" event can happen and she "need [s] protection" because there is interdependent relationship between the mother and the children (Nagarajan, 1998, p. 272). Rita DasGupta Sherma stresses that "motherhood is highly honored in Hindu kinship systems, it seems that this honor is based on her-negation, the ability to endure privations for the family, and the willingness to nurture and give sustenance, no matter what the sacrifice, with no thought of her own needs" (Sherma, 1998, p. 97). The relationship is built in a genuineness of being. The articulation of environmental problems makes an appeal for venerating the Earth, both for her sake, and for the sake of human welfare:

We venerate Mother Earth, the sustainer and preserver of forests, vegetation, and all things that are held together firmly.

She is the source of a stable environment.

Without remembering Mother Earth, forests disappear, water becomes foul and the air becomes unbreathable (Chapple, 2007, p. 210).

The stanza emphasizes that consciousness becomes the key of a stable relationship between Mother Earth and children. Chapple states "without the feminine creative principle, life would be impossible" (Chapple, 2007, p. 210).

\section{St. Francis of Assisi}

One of the Christian mystics is St. Francis of Assisi (1182-1226 C.E) who composed the Canticle of Creatures (Canticle of Brother Sun) in 1225 C.E. St. Francis of Assisi expressed most beautifully his contemplation with God through the creation:

Most High, all-powerful, and all-good Lord,

Praise, glory, honor,

and all blessing

are yours.

To you alone, Most High, they belong, although no one is worthy

to say your name.

Praised be my Lord, with all your creatures, especially my Lord Brother Sun, through whom you give us day and light Beautifully he shines with great splendor: Most High, he bears your likeness.

Praised be my Lord, by Sister Moon and Stars: in the heavens you made them bright and precious and beautiful.

Praised be my Lord, my Brother Wind, and air and cloud and calm and all weather 
through which you sustain

your creatures.

Praised be my Lord, by Sister Water,

who is so helpful and humble

and precious and pure.

Praised be my Lord, by Brother Fire, through whom you brighten the night: who is beautiful and playful

and sinuous and strong.

Praised be my Lord, by our Sister Mother Earth, who sustains us and guides us, and provides varied fruits

with colorful flowers and herbs.

Praised and blessed be you, my Lord, and gratitude and service be given to you with great humility (Hart, 2006: 28-29).

St. Francis of Assisi contemplates a deep relationship triangle between human, cosmos, and God. Eric Doyle, a Franciscan priest, in his book St. Francis and The Song of Brotherhood points out the Canticle of Creatures illustrates a "mystical enlightenment" which means "absolute and indiscriminate" and "more than ordinary language to express them" (Doyle, 1981, p. 38). Furthermore, Doyle stresses that St. Francis of Assisi composes the canticle "as a prayer of praise to God the Creator the Canticle is a sublime expression of the authentic Christian attitude to creation, which is to accept and love creatures as they are" (Doyle, 1981, p. 40). Since the $12^{\text {th }}$ century, an environment's problems existed because of the selfishness of humans; it became the background to St. Francis of Assisi's writing the Canticle of Creatures. The classic text of St. Francis of Assisi shows his concern, "I want ... to make a new Song of Praise of the Lord for his creatures, which we use daily and without which we could not live. In them the human race greatly offends the Creator" (Doyle, 1981, p. 67).

Besides the $12^{\text {th }}$ century context, John Hart in his book Sacrament Commons: Christian Ecological Ethics affirms that the Canticle of Creatures "did not emerge in a spiritual vacuum" (Hart, 2006, p. 26). As evidence, when the Canticle of Creatures "is compared with Psalm 148 and Daniel 3, that [St.] Francis [of Assisi] drew upon these earlier sources, which linked his nature mysticism to his Christian biblical tradition, to express in song and his own language his appreciation for the wonders of the Spirit in creation" (Hart, 2006, p. 27). In the first three verses, St. Francis of Assisi praises the Lord through all creation. This is comparable with the story of Genesis about "the habitation by the living creatures who will be created to dwell in air, water, and land in the next three days of creation" (Hart, 2006, p. 30). St. Francis of Assisi entitles Brother and Sister for the four basic elements: air (wind), water, fire and earth, and for the sun, moon and stars. For the earth, he has a special title: sister and mother. These show that St. Francis of Assisi puts himself as a part of the "kinship with all creation" and gives "appreciation for the biotic community (Hart, 2006, p. 30-31). There is no separation between human and other creations.

Both Hindu mythology and the Canticle of St. Francis of Assisi employ a personification of kinship for creatures, specifically the image of mother for the earth. The Mother Earth or "the Tellus Mater is a primordial image ... as the Primordial Mother who brought us forth from dark depths of her womb. 
[Mother Earth] is the origin and paradigm of all parturition, physical, intellectual and spiritual" (Doyle, 1981, p. 121). Mother Earth is the intersection symbol in the sense of kinship, community life, and interdependency. The kinship involves the whole participation of the female and male gender. The male gender is represented by the God as the consort of the goddess in Hindu mythology. Heinrich Zimmer highlights that "the God and the Goddess are the first self-revelation of the Absolute" (Zimmer, 1992, p. 139). In Christian theology, the Father, the male image, is a common image for God.

\section{The Four Basic Elements of Creation and Sacramental Aspect}

Hindu mythology describes that the creation has four basic elements: earth (soil), water, fire, and air (wind). The four basic elements are not merely material but they are attributed to the deva or devi. In Hindu mythology, there are stanzas as a gratitude to the four basic elements:

The waters in the sky, the waters of rivers, the waters in wells whose source is the ocean, may all these sacred waters protect me.

May plants, the waters, and sky preserve us, and wood and mountains with their trees for tresses ...

May the swift wanderer, Lord of refreshments, list our songs, who speeds through cloudy heaven.

And may the waters, bright like castles, hear us, as the blow onward from the cloven mountain (Chapple, 2007, p. 205).

Satish Kumar in his chapter "Three Dimensions of Ecology: Soil, Soul and Society" emphasizes "the earth is a living organism ... nature is intelligent and conscious. The elements earth, air, fire and water have divinity intrinsic to them. Hindus talk about the rain god Indra, the wind god Vayu, the fire goddess Agni and the earth goddess Bhumi [italics are added]" (Kumar, 2014, p. 132). The value of the four basic elements become part of our lives because they are also connected to the god and the goddess.

The four basic elements are connected with sacred meaning. This emerges from the concept of panentheism and not pantheism, as Kumar echoes a Hindu scholar, Vinoba Bhave:

God is everywhere in the Universe. As holy rivers, high mountains, serene oceans, tender-hearted cows, noble horses, majestic lions, sweet voiced cuckoos, beautiful peacocks, clean and solitude loving snacks, crows flapping their wings, the upward rising flames, the still stars-He is pervading the whole creation in different forms. We should train our eyes to see Him everywhere (Kumar, 2014, p. 132).

It is very interesting that St. Francis of Assisi includes the four basic elements in the Canticle of Creatures. By saying: "Praised be my Lord" before mentioning "Brother Wind," "Sister Water," "Brother Fire," and "Sister Mother Earth," St. Francis of Assisi implicitly emphasizes the existence of them being associated with God. Hart highlights that "there is no rivalry among these siblings but rather a mutuality of interests in a familial relationship" (Hart, 2006, p. 33). The presence of wind, water, fire, and earth (soil) become a "bridge [between] the heavens and the Earth" (Hart, 2006, p. 29). Additionally, St. Francis of Assisi calls them in the kinship language: brother and sister. This shows the intimate relationship between living beings and human beings. Kinship is togetherness.

Both Hindu mythology and the Canticle of St. Francis of Assisi use the ancient four basic elements of creation, which are very common across continents. The intersection of the four basic elements confirms two things. First is the divine or the sacred dimension implanted in the four basic elements. The spirit of God is in the four basic elements. This is teaching humans about 'how to see' that in the 
soil there is the spirit. The second is the four basic elements, as living beings, are siblings of us as human beings. To be humble toward living beings is a necessity. All of these are form a triangle of intimate relationship between God, living beings, and human beings as argument against anthropomorphism.

In Hindu mythology, the sacred is embedded in the creation itself. Jain points out that there are two models of environmental practices: "devotional" and "ascetic" (Jain, 2011, p. 7-8). The devotional model emphasizes on "ritualistic [practice] toward a deity," or "honor [to] the Devi" (Jain, 2011, p. 7; Chapple, 2007, p. 204). As an example, "Sarasvati can be seen as a harbinger of ecological insight, combining the physical reality of a river with the symbolic importance of intellect, purity, and refinement" (Chapple, 2007, p. 205). The ascetic model emphasizes on "non-violence to animals, trees, and self, combined with non-possessiveness can result in ecological awareness" (Chapple, 2007, p. 8). This model gives rise for someone to be a vegetarian. Jain suggests both models "to create a symbiotic model using both asceticism and devotion" (Jain, 2011, p. 10). There is obvious understanding of the sacrament in the devotional and ascetic practices, which refers to panentheism rather than pantheism.

Additionally, the sacramental aspect in Hindu mythology on creation can be seen as a "trinity in Sanskrit [which] is yagna, tapas and dana" (Kumar, 2014, p. 129). Kumar explains "yagna relates to human/ nature relationship, tapas relates to human/ divine relationships and dana relates to human/ human relationships" (Kumar, 2014, p. 129). He translates the three aspects into English as "soil, soul and society" and as an "inclusive of ecology, spirituality and humanity" (Kumar, 2014, p. 129). As Arvind Sharma says in his chapter "Attitude to Nature in the Early Upanisads," mentions "dhyayativa prthivi" meaning "the earth ... is in a state of meditation" because the inclusive relationship creates an "ecologists ecstatic'" (Sharma, 1998, p. 55).

St. Francis of Assisi in the Canticles of Creatures shows how he "contemplated creation, cared for creation and communed with the Creator through creation" (Hart, 2006, p. 23). Those actions demonstrate that humans should be aware of "creation as a sacramental universe" in his/ her daily life (Hart, 2006, p. 23). Hart highlights, "Creation is sacred in itself, not just as the bearer of the divine Being. Creation has intrinsic value, not just instrument value as a provider of goods or mediation of the Spirit" (Hart, 2006, p. 33). Creation as a mediation has three dimensions of locus: "interactive, interdependent and integrated relationship" (Hart, 2006, p. 33). Richard Rohr, a Franciscan priest, in his chapter "Christianity and the Creation" explains that St. Francis of Assisi "sees an interdependence between the different layers of creation ... [It] comes out of a mystical insight, a contemplative insight, an sight that recognizes that we are a part of this great chain of being, that these are brothers and sisters, and therefore we may not disrespect them" (Rohr, 1994, p. 134-135). Furthermore, Hart highlights that the Canticle of Creation should be understood through panentheism since "a panentheistic perspective provides insights into the Creator Spirit's loving engagement with creatures" (Hart, 2006, p. 34).

The most important part in both Hindu mythology and the Canticles of Creatures about the sacredness is embedded in the intersection between the divine and the earth. The intersection itself is sacramental. Larry L. Rasmussen in his book Earth Community Earth Ethics, describes an obvious meaning of the sacrament of creation:

Sometimes called 'panentheism,' sacramentalism recognizes and celebrates the divine in, with, and under all nature, ourselves included. Creaturely is not identified as God, however. (This is pantheism, not panentheism.) Nature and the world are thus not themselves divine and are not worshiped. Rather, the infinite is a dimension of the finite; the transcendent is immanent; the sacred is the ordinary in another, numinous light - without any one of these term exhausting the other. Sacrament themselves are symbols and sign that participate in the very Reality to which they point, 
but they are not themselves worshiped. To identify something earthly as holy and sacred is not to say is God. Rather, it is of God; God is present in its presence (Rasmussen, 2000, p. 239).

Even though, the term of sacrament is rooted in Christianity but the insightful meaning is also found in Hindu mythology. Panentheism is found in Hinduism and Christianity.

\section{Eco-spirituality}

The intersection between Hindu Bhumi Devi and the Canticle of Creation shows an insight of cosmological health which is created from the mind to the heart. There is a synthesis between interior and exterior ecology through a mystical approach. Based on the mystical experience for the interreligious movement, I propose three aspects of eco-spirituality: the values of intersections, "how to see," and ecological consciousness. The three aspects are interwoven and they are flowing like water from upper course to lower course of river, which is mystical kinship of creation.

\section{The Values of Intersections}

As I mentioned previously, eco-spirituality extracts spiritual aspects from the ecology itself and not from any particular tradition. Alister McGrath, historical theology scholar, in his book Creation, states, "When we see nature as God's creation, it changes not merely in meaning but in value (McGrath, 2005, p. 14). The values are embedded in the existence of the creation itself. In the previous discussion on the concept of Bhumi Devi and the Canticle of Creation, I proposed three intersections: the personification of creation, the four basic elements of creation and its sacramental aspects; those are valuable foundations for eco-spirituality. They are the values of creation. Hart emphasizes that "creation has intrinsic value not just instrumental value [italics are added]" (Hart, 2006, p. 33).

The first value is that the Mother Earth is not a thing but a being. As human beings, we are born, grown, and work on the earth. The symbolic of mother bears an essential value of who we are as humans. In other words, on the one hand, one can claim to be a human, but on the other hand, he or she neglects the existence of Mother Earth. Mother Earth is the life source.

The second value is that the four basic elements are alive, not dead objects because they, water, soil, fire, and air, are connected to the divine Being. Without the four basic elements, all creatures cannot exist. This is the value of interdependency behind the symbolic meaning of kinship. The kinship of creation focuses on "their interactive and interdependent and integrated relationship" (Hart, 2006, p. 33). The kinship includes the whole family: siblings and mother and father. Both the concept of Bhumi Devi and the Canticles of Creation demonstrate an ecological incarnation. Heaven and earth are connected as shown in Hindu mythology, especially, the Vedic tradition:

May Heaven and Earth make food swell plenteously for us,

All-knowing Father, Mother, wondrous in their works.

Pouring out bounties, may, in union, both the Worlds,

All beneficial, send us gain, and power, and wealth (Chapple, 2007, p. 204).

Jain highlights that indwelling God in the Mother Earth shows the "brotherhood [and sisterhood] of humans under the fatherhood of God" (Jain, 2011, p. 18). The kinship of Creator is not just with humans but with all creatures. In other words, the supernatural is manifest in natural reality.

The third value is the manifestation of supernatural Reality into natural reality. More than a way of manifestation, which is known by term "panentheism" is found in the ancient tradition such as Hindu mythology and the Canticle of Creation. Panentheism or sacramentalism becomes the point of 
intersection between Hinduism and Christianity. Then it creates appreciation of creation in ordinary life in which humans find the sacred is in the profane itself. There is non-duality as the quality of creation. All of the values are the wisdom facets in creating eco-spirituality.

\section{"How to See"}

On the Hindu perspective, Nagarajan highlights that "embedded ecology is sacred geographies, where particular rivers, soils, groves, and mountains are imbued with sacrality. In such cases geography describes a religious landscape" (Nagarajan, 1998, p. 281). Thomas Berry, a Catholic priest and ecotheologian, lines up with Nagarajan. Berry says: "The spirituality of the Earth refers to a quality of the Earth itself, not human spirituality with special reference to the planet Earth. Earth is the maternal principle out of which we are born and from which we derive all that we are and all that we have ... Earth is our origin, our nourishment, our educator, our healer, our fulfillment." (Berry, 2009, p. 69). Both Hinduism and Christianity have similar perspective on the spiritual aspect from ecology itself. The ecology is a positive energy resource for living and a human response is needed. Rohr gives an idea about "how to see" [italics are added] the creation in a positive way (Rohr, 1994, p. 132). Based on the Christian teaching from the Bible, Rohr underlines "original blessing" rather than "original sin" in the story of creation (Rohr, 1994, p. 137). Rohr explains "Once we learn how to see, how to contemplate, how to let the moon and the sun and the stars and the seasons and the trees and the plants and the animals speak to us; once we find our instinctual self in the eyes of animals, then we are ready to go and study theology [spirituality]" (Rohr, 1994, p. 139). Spirituality is a way of life, which engages the self, world, and God or the Ultimate Reality. In spirituality, there is an intersection between vertical and horizontal relationships.

In Hinduism, the intersecting relationship refers to dharma. "Dharma" is a "combination of ethics (in human world), ecology (in natural world), and theology (in the spiritual world)" (Jain, 2011, p. 120). Dharma has two fundamental aspects: duty and virtue, which are blended with each other. This makes dharma not only about action, but also contemplation. Moreover, Jain describes that "the subjective dharma is concerned with inner purification, purification of the mind, inner discipline; the objective dharma is concerned with duties, including universal or common duties and those duties that depend on a person's particular position in society and stage of life" (Jain, 2011, p. 124). Jain's idea resembles Rohr's and Hart's ideas. All of these ideas draw someone to realize that "I am a microcosm of the macrocosm" as Kumar said (Kumar, 2014, p. 137).

As I mention above, panentheism or sacramentalism is the core of eco-spirituality. Based on the basic meaning of spirituality as a way of life, the sacrament of nature persuades people in the midst of macrocosm is "wonder, awe, amazement, fascination, astonishment, curiosity, and surprise. It is also a sense of being very small amidst a grand Reality" (Rasmussen, 2000, p. 239). This consciousness raises human attitudes from controlling, mastering, or to make a distance relationship with creation. Rasmussen reminds us that this is not a new idea in approaching nature because for "native peoples generally everything in nature represents transcendent power and order, and all the activities of culture - farming, hunting, cooking, eating, householding - are sacramental. They are visible signs of divine power and presence amidst daily practices" (Rasmussen, 2000, p. 239). David Tacey, lines up with Rasmussen, who states, "Religion had taught me to find God in heaven. Aboriginality had shown me to find the sacred on earth" (Tacey, 2004, p. 6). Both Rasmussen and Tacey affirm that inside of local wisdoms, there are teaching of how to see ecology. 
O. P. Dwivedi in his chapter "Hindu Religion and Environmental Well-Being" points out that in discussing ecology, the concept of "dharma" should be tied together with "karma-pala," which means fruits, effects or consequences of action. Additionally, Dwivedi says:

The law related to karma tells us that every action performed creates its own chain of reactions and events, some of which are immediately visible, while others take time to surface ... Every action its own reaction. What is important to know is that right action, that is dharmic action, generates beneficial results, while adharmic action results in harmful effect (Dwivedi, 2006, p. 169).

Furthermore, Dwivedi argues that, "the Hindu heritage for eco-spirituality can lead us to control our base characteristics such as greed, exploitation, abuse, mistreatment, and defilement of nature. But before we can hope to change the exploitative tendencies, it is absolutely essential that we discipline our inner thoughts [italics are added]" (Dwivedi, 2006, p. 173). Dwivedi stresses a necessity for inner transformation of each person as the basic foundation in proposing eco-spirituality for human beings.

More profoundly, Willis Jenkins, in his book Ecologies of Grace, echoes Matthew Fox, "there can be no anthropology without cosmology" (Jenkins, 2008, p. 97). In other words, human beings are nothing without the cosmos, the universe. This reminds us about the concept of Bhumi Devi as our mother because the entire sustainability of life in the world depends on her. According to Christian beliefs, Jenkins lines up with Rohr. While Rohr suggests "original blessing" as a theological foundation for eco-spirituality, Jenkins proposes "grace of nature" as the "strategy of ecological spirituality" (Jenkins, 2008, p. 98). The way of "how to see" the earth is also found in Hindu mythology:

Irrespective of the place and region where we are,

whether in a rural area, in the woods,

in the battleground, or in a public place,

may we always sing your praises (Chapple, 2007, p. 206).

\section{Ecological Consciousness}

The way of "how to see" encourages us to go into a deeper level which is consciousness. Sherma argues that consciousness is not something that originates in some transcendent world outside of the nature, but in the place where "nature itself becomes conscious" (Sherma, 1998, p. 92). Additionally, Shema affirms, "Ecofeminist spirituality tends to envision the divine not as ruler or heavenly monarch, nor as a removed and distant higher reality, but as 'the immanent source of life that sustains the whole planetary community" (Sherma, 1998, p. 93). Ecofeminist perspectives have similar ideas of the divine incarnation through nature and panentheism or sacramentalism. This is a valuable contribution from Hindu ecofeminist spirituality. Sherma explains that according to tantric doctrine, Sakti contains all aspect of life:

Through a process of devolution, Sakti first manifest as (a) citsakti the power of consciousness, then as (b) maya-sakti the power which veils the unity underlying the multiplicity of phenomena and creates the appearance of manifold realities, and finally as (c) embodied life in her form as prakrti-saki, the primordial substance of the universe. She is the energy that move in the cosmic cycles of creation [italics are added], preservation, destruction (or reabsorption into herself) and recreation. Because she is the force of consciousness inherent in all things, and indeed because all things are actually modes of her being, the natural is imbued with sanctity (Sherma, 1998, p. 111).

The embodiment of Sakti in the cosmic cycles of creation influences humans' response to the natural dynamic of creation, such as a volcano eruption. Humans should not blame the mountain or God because of the eruption. This reminds me, as a Javanese who live in Yogyakarta, special province of Indonesia, and the center of Javanese culture, of when Merapi mountain in Yogyakarta erupted in 2010. It was a 
disaster for more than two weeks, all activities: schools, offices, markets were closed because the volcanic materials covered Yogyakarta city. On the one hand, thousands residents, who are originally not Yogyakarta people, moved to their relatives' houses in other cities. On the other hand, the original residents of Yogyakarta stayed peacefully in the midst of the eruption. More than that, in many intersections, there were banners with words on it: "Apapun yang terjadi, Merapi adalah sahabat kawulo Ngajogjakarta," which means "Whatever is happening right now, Merapi is friend of Yogyakarta's people." In Javanese perspective, eruption is like a coin. On the one side is disaster but in the other side is blessing. The eruption of Merapi creates fertile soil and new opportunity by "the Divine Mother is sakti" (Sherma, 1998, p. 116). Blaming Merapi mountain is taboo in Yogyakarta. This is a concrete consciousness of the cosmic cycle of creation in which "the microcosm reflects the macrocosm" (Sharma, 1998, p. 112).

The ecological consciousness construct of cosmotheandric, the unification of theos, anthopos, and cosmos comes from Raimon Panikkar's thought. Panikkar in his book The Cosmotheandric Experience, emphasizes that "our relation with the Earth is part of our self-understanding. It is a constructive relationship. To be entails being in and with the World" (Panikkar, 1993, p. 151). Panikkar's idea of cosmotheandric can be useful way to counter anthropomorphism because there is an opposite approach to the cosmos. Indeed, Panikkar stresses:

The Earth is neither inferior to Man nor superior. Man is neither boss of this World, nor just a creature, the product of a cosmic Womb. The Earth is also not "equal" to Man. Equality assumes a higher genus of which the two species are precisely equal specimens. Man and the cosmos, to the contrary, are ultimates, and thus reducible neither one to the other nor to a higher entity. The relation is non-dualistic. Both are distinct, but not separable (Panikkar, 1993, p. 150).

The concept of cosmotheandric helps humans "how to see" and put his or her position in the universe. Panikkar reminds us that in Indian tradition, two words of the Earth are bhümi which "exists here before us, that which 'natures' all of all nature, all the things of this world [and the other word] is prthvī, which stretches out before us in an ever-expanding horizon, that which receives all the steps we make, all the growth that may occur in us" (Panikkar, 1993, p. 138). These ideas underline the intimate relationship beyond the physical connection, what is more is "the intrinsic connection between Life and Being at the deepest level" (Panikkar, 1993, p. 141). This discussion reminds me, as an Indonesian, of an Indonesian national song "Kulihat Ibu Pertiwi," which means "I see Mother Pertiwi." Mother Pertiwi means "Mother country." For Indonesians, the song has been introduced to children since elementary school:

Kulihat ibu pertiwi (I see Mother Pertiwi)

Sedang bersusah hati ([She is] in sorrow)

Air matanya berlinang (Your tears are flowing)

$[\ldots]$

Kini ibu sedang lara (Now Mother is grieving)

Merintih dan berdoa (Sighing sadly and praying)

The grieving and the sighing of Ibu Pertiwi reveal the global ecological crisis. This song teaches Indonesians to take care of the earth as a mother and a homeland. They show the responsibilities of Indonesians, as sons and daughters, to serve and to be compassionate with Mother Pertiwi who is grieving. This personification expresses a kinship of creation.

\section{Mystical Kinship of Creation}


Humanity needs, especially in the hypermodern era, an intimacy with the Earth which is evidence that humans are alienated from this earth. This is an ironic reality because when humans discuss about ecology or environmental crises, the problem is not in the environment itself but in the inner human self. Doyle highlights that the human is in "the inner human problem of alienation as well as selfishness. Man is alienated from him [her] self and this has alienated him [her] from the rest of creation" (Doyle, 1981, p. 51). Doyle reflects on St. Francis of Assisi who proposes "homo universalis, " meaning a universemen, because "homo sapiens," which means an earthmen, is not enough (Doyle, 1981, p. 51). Berry affirms, "What is needed is a new spiritual, even mystical, communion with Earth, a true aesthetic of Earth, a sensitivity to Earth's need, a valid economy of Earth" (Berry, 2009, p. 73). Mystical relationship between humans and the Earth is a necessity.

Leonardo Boff, a liberation theologian, in his book Ecology \& Liberation, proposes that "the world is not only a bridge to God. It is also a place where God is honored and worshiped, and the place where we meet God" (Boff, 1995, p. 51). Again, panentheism plays an insightful role in the mystical kinship for all creatures. Boff points out: Panentheism is a most appropriate way of embracing and encompassing the universe, for it means that we are always in a state of approaching one and the same trinitarian God. This experience gives rise to a new integrative and holistic spirituality that can unite heaven and earth (Boff, 1995, p. 51). The emphasis is not only from Christianity, but also from Hinduism, as Lance E. Nelson proposes, "If one can understand spirit, nature, and their relationship in the Advaitic way [meaning longing liberation from all form], thus attaining freedom and detachment, the world becomes 'value-laden' and 'a natural reverence then becomes one's basic attitude with nature" (Nelson, 1998, p. 73). Both Boff and Nelson awaken a mystical or intimate relationship of creatures based on creation myths. Mystical kinship plays an important role in the functioning of myth.

Matthew Fox argues that "the first function of mythology ... is to awaken in the individual as a sense of awe, wonder, and participation in the inscrutable mystery of being." (Fox, 1991, p. 30-31). The myth becomes a valuable aspect for reawakening in approaching mystical kinship of ecology because "nourishing spirituality means cultivating that inward space, the basis of which all things can be brought together" (Boff, 1995, p. 37). The process of cultivation goes from the inward space to the outward action. This is the essence of spirituality as a way of life. Spirituality must be seen concretely in daily life. In other words, mystical kinship of ecology becomes immanent in ordinary life through cosmic consciousness. The mystical kinship of creation becomes our being and living. Rasmussen affirms, "We don't live on earth, but in earth as earth" (Rasmussen, 2006, p. 268). Eco-spirituality manifests into caretaking for creation as Hart proposes:

Care about creation: people are lovingly concerned about the integral universe emerging from the vision and through the creativity of the Spirit. Care for creation: people responsibly use their intellect and skills to integrate the needs of ecosystems and of Earth ... Care in creation: people respect and serve creation as their community, home, and habitat, and live as biotic kin in the biotic community, concern about individual and species well-being (Hart, 2006, p. 67).

Caretaking for creation, as a manifestation of mystical kinship of ecology, is being proposed for communion well-being. This is against the individualism and consumerism across centuries, and even more so for the hypermodern society. Mahatma Gandhi as the great Indian leader says, "Nature provides enough for everybody's need but not enough for even one person's greed" (Kumar, 2014, p. 133). Gandhi's dictum expresses a deep eco-spirituality in which humans must be able to make a distinction between human need and human greed. 


\section{Conclusion}

Movements of environmentalism around the world have a slogan, "Go Green!" My question is "What precisely is meant by this slogan?" As I quote in the introduction, environmentalism is not just about ecological activity, but it is more about reconstruction of eco-spirituality through mystical kinship of creation. The intersection between Bhumi Devi and the Canticle of Creatures demonstrate an interspirituality of Hinduism and Christianity. The interspirituality between Bhumi Devi and the Canticle of Creatures is a vocation for the hypermodern world that human life is not always a step forward to the future, but also should reflect on the past. Mystical kinship of creation is not a new idea because it is rooted deeply in the classical wisdom of creation that can be valued as the foundation for interreligious ecological movements now days. All religions and beliefs have responsibility toward ecological crisis as a global problem. Of course it is not just a responsibility of environmentalism activists, but what we need is to think globally - act locally which means mystical kinship of creation as the foundation of ecospirituality should be practiced by each person. Ecological crisis is an inner human problem across genders, socio-economic statuses, ethnicities, religions, and nations.

\section{References}

Berry, Thomas. (2009). The Sacred Universe: Earth, Spirituality, and Religion in the Twenty-first Century. New York: Columbia University Press.

Boff, Leonardo. (1995). Ecology \& Liberation: A New Paradigm. Maryknoll: Orbis Books.

Chapple, Christopher Key. (2007). "The Goddess and Ecological Sensitivity: the Cultivation of Earth Knowledge." In The Constant and Changing Faces of the Goddess: Goddess Traditions of Asia, Ed. Phyllis Herman, Deepak Shimkhada, 204-219. Newcastle upon Tyne, UK: Cambridge Scholars Publishing.

Doyle, Eric. (1981). St. Francis and the Song of Brotherhood. New York: The Seabury Press.

Dwivedi, O. P. (2006). "Hindu Religion and Environmental well-Being." In The Oxford Handbook of Religion and Ecology, Ed. Roger R. Gottlieb, 160-183. New York: Oxford University Press.

Fox, Matthew. (1991). Creation Spirituality: Liberating Gifts for the Peoples of the Earth. New York: HarperSanFrancisco.

Hart, John. (2006). Sacramental Commons: Christian Ecological Ethics. Lanham, Maryland: Rowman \& Littlefield Publishers.

Jain, Pankaj. (2011). Dharma and Ecology of Hindu Communities: Sustenance and Sustainability. Burlington, VT: Ashgate Publishing Company.

Jenkins, Willis. (2008). Ecologies of Grace: Environmental Ethics and Christian Theology. New York: Oxford University Press.

Kumar, Satish. (2014). “Three Dimensions of Ecology: Soil, Soul and Society.” In Spiritual Ecology: The Cry of the Earth, Ed. Llewellyn Vaughan-Lee, 129-141. Point Reyes, California: The Golden Sufi Center.

Lincoln, V. (2000). Eco-spirituality: A Pattern that Connects. Journal of Holistic Nursing, 18(3), 227244. doi: 10.1177/089801010001800305

McGrath, Alister. (2005). Creation. Minneapolis: Fortress Press.

Nagarajan, Vijaya Rettakudi. (1998). "The Earth as Goddess Bhu Devi: Toward a Theory of 'Embedded Ecologies' in Folk Hinduism." In Purifying the Earthly Body of God: Religion and Ecology in Hindu India, Ed. Lance E. Nelson, 269-295. New York: State University of New York Press. 
Nelson, Lance E. (1998). "The Dualism of Nondualism: Advaita Vedanta and the Irrelevance of Nature." In Purifying the Earthly Body of God: Religion and Ecology in Hindu India, Ed. Lance E. Nelson, 61-88. New York: State University of New York Press.

Panikkar, Raimon. (1993). The Cosmotheandric Experience: Emerging Religious Consciousness. Maryknoll: Orbis Books.

Pilario, D. F. E. (2020). Interdisciplinary Perspectives and Approaches in Theologizing in Asia. International Journal of Indonesian Philosophy \& Theology, 1(1), 27-40. doi: 10.47043/ijipth.v1i1.4

Rampisela, D. A. (2020). Transdisciplinary Research Bridges the Gap between Science and Pastoral Services. Jurnal Jaffray, 18(1), 95-105. doi: 10.25278/jj.v18i1.411

Rasmussen, Larry 1. (2000). Earth Community Earth Ethics. Maryknoll, New York: Orbis Books. . (2006). "Ecology and Morality." In Religion and the New Ecology: Environmental Responsibility in a World in Flux, Ed. David M. Lodge and Christopher Hamlin, 246-278. Notre Dame, IN: University of Notre Dame Press.

Rohr, Richard. (1994). "Christianity and the Creation: A Franciscan Speaks to Franciscans." In Embracing Earth: Catholic Approaches to Ecology, Ed. Albert J. LaChance and John E. Carroll, 129-155. Maryknoll: Orbis Books.

Sharma, Arvind. (1998). "Attitudes to Nature in the Early Upanisads." In Purifying the Earthly Body of God: Religion and Ecology in Hindu India, Ed. Lance E. Nelson, 51-60. New York: State University of New York Press.

Sherma, Rita DasGupta. 1998. "Sacred Immanence: Reflections of Ecofeminism in Hindu Tantra." In Purifying the Earthly Body of God: Religion and Ecology in Hindu India, Ed. Lance E. Nelson, 89-131. New York: State University of New York Press.

Tacey, David. 2004. The Spirituality Revolution: The Emergence of Contemporary Spirituality. Hove and New York: Brunner-Rougtledge.

Wilfred, F. (2020). Asian Theological Ferment (For Doing Theology in Contemporary Indonesia: Interdisciplinary Perspectives). International Journal of Indonesian Philosophy \& Theology, 1(2), 73-90. doi: 10.47043/ijipth.v1i2.11

Zimmer, Heinrich. (1992). Myths and Symbols in Indian Art and Civilization. New Jersey: Princeton University Press. 